\title{
The Work of the Overseas Food Corporation in Relation to the British Diet
}

\author{
By N. R. Fuggles-Couchman, The Overseas Food Corporation, \\ $3 \mathrm{I}$ and 33 Hill Street, London, $W$. I
}

It is well known that the Overseas Food Corporation is responsible for the management of the East African Groundnut Scheme. It is not so widely appreciated that it is also responsible for the Sorghum and Pig Project begun in Queensland. Unfortunately, the groundnut scheme has been too much in the political limelight, and headlines and biased comments have tended to obscure the reasons for the conception of, and the need for, such a scheme. There has been a tendency to overlook the magnitude of the task which was set, and to judge the future of the scheme on the results of its first 2 years of development of uninhabited, waterless, largely roadless African bush.

\section{World shortage of fats}

It therefore seems desirable for me to re-state the facts which led to the decision that such a scheme was necessary before explaining how it is hoped that the work of the Corporation will make its contribution to the British diet.

In 1946 , the world food position in general, and that of the British Isles in particular, gave rise to serious concern. We believe now that at least some of this anxiety was not well founded. For instance, production of grain has largely caught up with requirements. But in one commodity especially, the position, as assessed in 1946, has not improved to the same extent. This is the important one of oils and fats. The shortage of oilseeds in importing countries has been variously estimated at $2,75^{\circ}, 000-4,000,000$ tons, and it is at present estimated that there is a $13 \%$ deficiency over the whole world. India and China used to export very large quantities, India $\mathrm{I}, 000,000$ tons/year, but they are now virtually non-exporters. India uses its products almost entirely, and China has been disrupted by internal wars.

\section{Shortage of fats in the United Kingdom}

Britain's position in this respect was, and is, an extremely precarious one. Though we can produce some $45-50 \%$ of our requirements in other foodstuffs, we depend upon imports of oils and fats to the extent of $97 \%$ of our needs. Previous consumption of all oils and fats in the United Kingdom was $60 \mathrm{lb}$./head. To-day it is only $49 \mathrm{lb}$. The Commonwealth can supply only some two-thirds of our present-day supplies, the rest being drawn from dollar or hard currency sources.

This shortage cannot be made good within the United Kingdom. Though there could possibly be a small contribution from the cultivation of sunflower and linseed, this would inevitably be at the expense of some other crop. Indirect increase in fats through more milk production, or more bacon, could be obtained; but feeding-stuffs, the most valuable oilseed residues, have to be imported. There is still more to it than this: oil 
crops are principally products of the hot, sunny areas of the world, being very largely tropical and subtropical. If there is to be an increase in production, it must come from regions with suitable climates.

\section{Proposed schemes to increase supplies}

Essentially, we must look to Commonwealth countries to fill the gap. As previously mentioned, India cannot contribute, Australia has suitable land, but no labour; the Far East is in a seriously troubled state; we are left with Africa, with its great empty areas, although not all suitable for agriculture, and its 50-60 million Africans.

The primitive nature of African agriculture, however, does not permit expansion to the extent required. In many years all their efforts fail to produce sufficient food even for themselves.

East Africa. Such was the position in 1946 , and is largely the position to-day. The United Kingdom requires more oils and fats, Africa has the land, but not the power to increase production sufficiently to fill the gap. From this appreciation of the position sprang the conception of the opening up of large areas of east and central Africa for the mechanized production of oilseeds, and in particular, groundnuts. A mission investigated the possibilities and reported favourably to the Government, who accepted their plan with some modification. The plan accepted was for the opening up of $3,210,000$ acres of bushland in east and central Africa. It was estimated that in full production the contribution to the United Kingdom oil intake would be 250,000 tons a year-roughly one-half of the shortage. The Overseas Food Corporation took charge of the project 18 months after its inception.

Queensland. The Corporation was also charged with the carrying out of projects for production or processing in places outside the United Kingdom of foodstuffs or agricultural products other than foodstuffs. Thus, a project for groundnut production put forward by the Queensland Government was investigated by a mission early in 1948, but the conditions did not appear favourable. The original proposal was therefore replaced by a project for the growing of sorghum on a series of over-grazed sheep properties, with the aim of feeding the grain to pigs.

\section{Development of the schemes}

Let me say straight away that it is not possible to state in precise terms what the contribution of these two schemes will be to the British diet.

East African Groundnut Scheme. The East African scheme was designed to grow groundnuts as the chief crop in the rotation, together with other crops as and when their suitability for large-scale mechanized production had been proved. The size of the original scheme, however, has had to be seriously reduced to keep within the statutory borrowing powers of the Corporation. The recast plan aims at producing 600,000 acres of cultivable land by 1954 . Though one cannot forecast what the rotation will be in 1954, as experimental work is proceeding concurrently with our development, the basis of the plan is for half the area to be sown to groundnuts annually. The remainder will be sown to sunflowers, sorghum and such other crops as experiment proves suitable, 
and will contain a proportion under a resting crop of grass. Among these other crops may well be soya beans and safflower. On this basis, if all goes well, the annual oil production might amount to some 57,000 tons, rather over one-tenth of the estimated shortage of fats, comprising roughly three-fifths groundnut oil and two-fifths sunflower oil. This is approximately equivalent to 63,000 tons of margarine. In addition, there would also be some 84,000 tons of valuable cattle cake, with its indirect contribution to food supplies.

The reasons for these qualified estimates must be understood. So many problems and difficulties have been encountered in the first 3 years of the project that it is impossible to be more definite. There is always the unpredictable element of African weather. For example, this year, even though planting rains have been good in the production area at Urambo, further development there this season is jeopardized by the prolonged drought in other areas of the territory, making necessary the use for relief of famine and drought of rolling stock required to support our efforts. One reason for sober optimism, however, is that the major development will be in a province which has rarely, if ever, known famine, and where the worst extremes of the East African climate may largely be avoided.

As previously mentioned, other crops are under trial and are necessary for good husbandry. One of the most valuable possibilities is sova bean. The climate and soils of the Southern Province, where the largest development will take place, should be well suited to this crop. It is a very desirable crop for rotational purposes and has wellknown nutritive qualities. Many varieties are under trial and results are reasonably promising. But any production of soya beans would reduce the area of sunflower in the rotation, and on an oil basis, somewhat reduce oil production. On the other hand, there is not the $30-50 \%$ waste material in the soya bean that there is in the sunflower as husks, and there would be a corresponding increase in cattle cake if this produce went to oil production. It might be desirable, however, to use such production directly for human food, e.g. as soya flour.

Although it should not be over-stressed, there is the further possibility of using the belts of natural woodland left along roads and around cleared areas for the production of oil-bearing trees. The climate, however, seriously reduces the choice of suitable trees.

Queensland scheme. The development of the second scheme, in Queensland, has been much more straightforward. Since March 1948, the Corporation has purchased 480,000 acres of land in central western Queensland. This area comprises seven old ranching properties on which the carrying capacity has been seriously reduced by overstocking and lack of grass husbandry. The country is largely open, rolling grassland, with some areas of lightly wooded land. The soils are deep black clay-loams of considerably fertility. They have never been ploughed before. About half this area is considered ideal for grain growing, the remainder being available for grazing. Careful management will no doubt increase its carrying capacity. As well as sorghum, it is probable that sunflowers and possibly soya beans will be sown in rotation and provide further crops for export to Britain.

In addition, the Corporation has bought three widely separated small areas nearer the 
coast, where irrigation is available. These will be the sites of piggeries, where the grain sorghum will be fed to outdoor pigs. It is intended that each unit shall carry some 200 breeding sows. The number of units which will finally be developed is dependent upon experience gained with the first experimental units and on the future trend in coarse grain prices.

A third activity of the Corporation is the fattening of store cattle on the sorghum stover and grass of the unploughed areas of the large properties.

It is impossible to give anything but rather vague estimates of the contribution which this scheme will make to the British diet, as the form in which our products will be exported to Britain will depend on future market movements. It is hoped that after I95 I the Corporation will produce annually an average of some 80,000 tons of grain sorghum. If all this were fed to pigs in Queensland some 200,000 carcasses might be produced annually. It is possible, however, that the pig side of the venture may be developed a little less rapidly than the grain growing, in which case the surplus grain would be shipped to Britain for animal feeding. From this production 6000 tons were shipped home in 1949. Pig-feeding trials with this grain, made by Dr Braude at the National Institute for Research in Dairying, University of Reading, were entirely satisfactory. In addition to the grain or bacon exported, the Corporation will also be fattening off several thousand head of stock for export to Britain.

This, briefly, is the measure of production at which the Corporation is aiming during the next 5 years. As each year goes by, it is hoped to send home increasing quantities of oilseeds, grain sorghum, bacon and meat up to the quantities mentioned. Meanwhile, it is hoped to establish production in East Africa on an economic basis. After that period, with more knowledge of the costs and possibilities, it may be possible slowly to expand that production. Even should that not be feasible, I believe that the Overseas Food Corporation will have made a very real contribution, not only to the diet of the people of this country, but to the fundamental knowledge required for the future development of empty lands in Africa and elsewhere.

\section{Commonwealth Contributions and British Requirement of Meat}

\section{By J. Hammond, School of Agriculture, University of Cambridge}

This country will always be dependent on overseas supplies of meat. Before the war approximately $40 \%$ of our meat supplies were imported but, owing to the ploughing up of pastures for wheat and potatoes, to the increase in the dairy industry for the supplying of fresh milk, and to the shortage of imported feeding-stuffs, we are now dependent on overseas supplies of meat to the extent of about $55 \%$.

The general situation as regards consumption here has been changed since prewar days, for the amount consumed is now limited by the rationing system rather than by the price, owing to the application of the food subsidies. During the time of shortages, quality in meat has been at a discount, but signs are now appearing that many people, where supplies have been increased, are failing to take up the ration if the quality of the 